\title{
Dialogue
}

\author{
Austronesian Youth Perspectives on Language Reclamation \\ and Maintenance \\ EMERSON LOPEZ ODANGO \\ Re-Presenting Melanesia: Ignoble Savages and Melanesian Alter-Natives \\ TARCISIUS KABUTAULAKA
}

A Sea of Warriors: Performing an Identity of Resilience and

Empowerment in the Face of Climate Change in the Pacific

CANDICE ELANNA STEINER

The Contemporary Pacific, Volume 27, Number I, 73-180

(C) 2015 by University of Hawai' i Press 

A Sea of Warriors: Performing
an Identity of Resilience and
Empowerment in the Face
of Climate Change in the Pacific

Candice Elanna Steiner

\begin{abstract}
We will continue to fight for our land, our existence, and our identity that is threatened by the impacts of climate change. We will never give up to climate change.

-350 Pacific, "Warrior Day of Action"
\end{abstract}

$\mathrm{I}_{\mathrm{t}}$ is estimated that by 2050-within the lifetime of many who may read this dialogue piece-the world will see the forced migration of about 75 million people in the Asia-Pacific region as a result of climate change (Oxfam 2009, 9). According to a 2009 Oxfam briefing paper, The Future Is Here: Climate Change in the Pacific, "For countries like Kiribati, Tuvalu, Tokelau, the Marshall Islands, Fiji, Vanuatu, Papua New Guinea and the Federated States of Micronesia, climate change is not something that could happen in the future, but something they are experiencing now" $(2009, \mathrm{I} 3)$. As Padma Lal and Kate Fortune explain in The Pacific Islands: An Encyclopedia, "The survival of some island states-including Kiribati, Tuvalu and Tokelau - and the economic, social and cultural viability of many others, is seen to be threatened by global 'greenhouse gas' emissions and other human influences on the global climate" (2000, 43). Such influences have been linked to intensified weather events and other environmental changes, including but not limited to drought, flooding, intense and frequent hurricanes, and rising sea levels ( $\mathrm{P}$ Lal and Fortune $2000,43) .^{1}$

Since the publication of Lal and Fortune's encyclopedia entry in 2000, global attention to climate change has increased considerably, with many local, national, and international bodies turning their efforts toward cli-

The Contemporary Pacific, Volume 27, Number I, I47-I80

(C) 2015 by University of Hawai'i Press 
mate change mitigation and adaptation strategies. In April 20I4, one of these organizations, the Intergovernmental Panel on Climate Change (IPCC), released its most alarming report to date (IPCC 20I4a, 20I4b), the highly anticipated update on the status of climate change emphasizing just how dire the situation has become. Islanders like Kiribati President Anote Tong have begun planning for the worst. During a presentation titled "The Impacts of Climate Change on Kiribati and the Pacific Islands Region: Risk and Resilience," held at the East-West Center in Honolulu, Hawai'i, on I3 March 20I4, Tong detailed his strategies for protecting the people of Kiribati and safeguarding their dignity as they respond to climate change. His goals include providing worker training to give people job skills that would be needed in a new environment and pushing for early relocation that would help to ensure that any mistakes made are made and fixed as early as possible (Tong 2014). Moving toward these goals, the Kiribati government has purchased land on Vanua Levu in Fiji for $\$ 8.77$ million, part of the nation's backup plan in case the resettlement of the entire Kiribati population becomes necessary (Griggs 20I4). This is one prominent example of a nation preparing for the possibility of losing its land.

But what does it mean to lose a land? The contemporary Pacific is already inundated with complex issues related to both its colonial past and its increasingly globalized present, with concerns about things like sovereignty, human rights, health and safety, education, employment, tourism, and cultural sustainability attracting considerable attention and debate. A future that involves the forced relocation of entire communities would further complicate these issues, raising questions that would need to be answered on international, national, local, and individual levels. As playwright, director, and University of Hawai'i professor Vilsoni Hereniko has articulated:

For anyone who has lived or lives on an island surrounded by the deep, beautiful, but dangerous sea, the thought that one day your island will be submerged under water and everyone and everything on it will disappear is a possibility too cruel to contemplate. And yet, this is happening in several islands in Oceania already, with more Islanders contemplating their imminent demise and what that would mean to them as a people, a culture, even a nation. How does it feel to be forced by the rising sea to abandon everything you hold dear and to flee to another country to live among strangers? If you had to choose, would you go, or would you stay? "I would rather die here. Without this piece of land that defines who I am, I am nothing." Is that what you would say? And should 
you choose to flee, how will you fare? Can you live with the knowledge that you have abandoned the "bones of your ancestors"? (ECOPAS and USP 20I3 b)

To Pacific Islanders, these islands are complex sites, sources, and sustainers of identity, culture, and continuity with the past. Moreover, as the Reverend Tafue Lusama, a church and community leader in Tuvalu, has explained, "Land is equivalent to life in our culture. [If] you lose your land, you are dead. So if your land has been gradually eroded by the sea, you are literally seeing or looking at your life being eaten away. It tells you that you won't be able to give life to your children and your grandchildren" (Dekker 20II). Loss of and forced separation from these sites would thus constitute a significant rupture in the lives, experiences, and identities of everyone involved.

It is thus easy to understand why reports, global talks, documentaries, and other discussions and sources place such emphasis on the region's great vulnerability (see, for example, Oxfam 2009; Galloway and others 20I0; March 20I0). But island vulnerability does not necessarily render Islanders helpless. Just as renowned Pacific scholar Epeli Hau'ofa expressed that "smallness is a state of mind" $(2008,3 \mathrm{I})$, so too is helplessness. While climate scientists and world leaders discuss and debate the extent of the climate problem, the possibilities for mitigation, and questions of responsibility, Islanders-some perhaps unaware of the science and politics of climate change but having experienced its effects firsthand (Jetnil-Kijiner 2OII) - have been working together to take action of their own, refusing to accept the identity of victim. Hau'ofa's words again come to mind:

There is a world of difference between viewing the Pacific as "islands in a far sea" and as "a sea of islands." The first emphasises dry surfaces in a vast ocean far from the centres of power. Focussing in this way stresses the smallness and remoteness of the islands. The second is a more holistic perspective in which things are seen in the totality of their relationships. $(2008,3 \mathrm{I})$

Similarly, there is a world of difference between viewing Islanders as climate-change victims in a far and rising sea and viewing them as a sea of warriors with the power to rise up against climate change. The first emphasizes helplessness and victimization, while the second acknowledges Islanders' agency and ability to work together-taking advantage of the relationships Hau'ofa highlighted-to make their voices heard and to effect change. As with many facets of life and culture in the Pacific and as implied by Hau'ofa's words, these warriors' greatest strength is in numbers. 
Importantly, Islanders have been making this distinction for themselves through activities that spotlight their unique skills and traditions-including song and dance performance-and convey their own lived experiences of culture and climate change. In this essay, I analyze the messages that Islander creators and performers have chosen to convey through three performance initiatives: the 20II Water Is Rising concert tour, spearheaded by then Director of the UCLA Center for Intercultural Performance Judy Mitoma; the Pacific Warrior Campaign, including both the 2013 Warrior Day of Action and the 2014 Canoe Building Day of Action, coordinated by the youth-led, grassroots organization 350 Pacific; and the multimedia dramatic performance Moana: The Rising of the Sea, which premiered on 6 December 2013 at the Japan-Pacific ICT Theatre at the University of the South Pacific (USP) in Suva, Fiji, ${ }^{2}$ through a collaboration between former Director of the Oceania Centre for Arts, Culture and Pacific Studies Vilsoni Hereniko, Oceania Dance Theatre Artistic Director Peter Rockford Espiritu, usp Head of Performing Arts Igelese Ete, and Pacific Outreach Coordinator Allan Alo. I argue that through such performative events, we can see that Islanders are actively shaping their identity in the face of climate change, choosing to view themselves not as drowning, but as fighting. While participants in these projects have clearly stated and acknowledged through performance that their islands and cultures are extremely vulnerable to the negative effects of climate change (UClA 20IIa, 20IIb; 350 Pacific 20I3 3 , 20I3e; ECOPAS and USP $2013 \mathrm{a}$, $2013 \mathrm{~b}$ ), their involvement in such efforts and the messages they convey show their determination to stand up and speak out for the future of their communities.

\section{The Events}

In October and November 20II, thirty-six performers from Kiribati, Tokelau, and Tuvalu toured fourteen US cities during the Water Is Rising tour, ${ }^{3}$ sharing with audiences their cultures' unique music and dance traditions and their perspectives on climate change through stage performances, panel presentations, and other educational activities (Water Is Rising 20I Ia). The project's producer, Judy Mitoma, first fell in love with the music and dance of Pacific Island cultures when, as a graduate student, she attended the 1980 Festival of Pacific Arts in Papua New Guinea. This love of Pacific performance arts and a deepening concern about climate change led her to develop the Water Is Rising project. She targeted Kiri- 
bati, Tokelau, and Tuvalu both because they are some of the smallest and most vulnerable countries in the Pacific and because their musics resonate very deeply with her (Mitoma, pers comm, I3 July 20I3).

Despite some roadblocks along the way, Mitoma was able to secure twelve performers from each location. ${ }^{4}$ The groups-Te Waa Mai Kiribati (Kiribati), Kai Te Gali Mai Nukunonu (Tokelau), and Pa Laumilo (Tuvalu)—were very interested in sharing their arts, taking the project as a creative challenge (Mitoma, pers comm, I3 July 20I3). More than that, some saw it as an opportunity for ordinary people to take action against climate change. During a panel discussion at the University of California, Los Angeles (UCLA), Mikaele Maiava, the representative for Kai Te Gali Mai Nukunonu, expressed the frustration he felt at the climate-change conferences he had attended in Alaska, Australia, and the Cook Islands:

Going to these meetings is sitting down, discussions going on, and you don't really feel that ... someone is doing something to actually protect your people. So you think of it, what can $I$ do, as a nonscientist, or just a dancer, or just a citizen? What can you do to actually help your people? When I heard about the project ... I, like, woke up and could not go to sleep. I said, "This is the chance." I am very proud of my culture and very proud of my identity and very proud of my land. So that's the reason why I use my dance-and I'm sure that goes to Kiribati and also brothers from Tuvalu - we use these talents and this culture that we have-this so unique culture-to bring out our human face. (UCLA 2OIIa)

Not content just to sit back and wait for others to solve their problems, the performers took to the stage to raise awareness about climate change through song and dance.

Maiava has been involved in another performance-based awareness project, the Pacific Warrior Campaign. On 2 March 20I3, 350 Pacificwhich "works with organizers across I 5 Pacific Island nations to highlight the vulnerabilities of our island countries to climate change while showcasing our strength and resilience as a people" (350 Pacific 20I3 $\mathrm{e}$ )-held a Warrior Day of Action. Representing all three regions of Oceania, groups and communities in the Marshall Islands, Fiji, Niue, Tokelau, Vanuatu, Tonga, Kiribati, Solomon Islands, Sāmoa, and Palau convened on their respective islands to perform "war challenges, songs, and dances" to convey their "message to the world that we stand in solidarity against the unwelcomed global reality that is climate change. We understand that the 
climate crisis is claiming our livelihoods but we will be silent no more. No longer will we act as the victims" (350 Pacific 20I3c). The campaign's two slogans, "We are not drowning. We are fighting" and "It's Iо०\% possible for us to be heard," further drive home Islanders' desire to maintain agency as climate change progresses (350 Pacific 20I3b, 20I3d). Several of the participating groups created videos of their respective Warrior Day of Action events, portions of which 350 Pacific compiled, along with photos, into a short video clip (350 Pacific 20I3a).

The Warriors convened again on I2 April 20I4 for the Canoe Building Day of Action, during which they began preparing canoes for a voyage across the Pacific to Australia to deliver a message to the fossil-fuel industry (350 Pacific 20I4a). In a description of the event and the Pacific Warrior Campaign as a whole, organizers explained that Australia, the Pacific Islands' biggest neighbor and both home to and historic supporter of many Pacific Island communities, is taking steps in the wrong direction when it comes to climate-change mitigation. The fossil-fuel industry, with the support of the Australian government, big lenders, and other proponents, is planning "gigantic new coal mines that would double Australia's coal exports," which "will have a devastating impact on the Pacific Islands" (350 Pacific 20I4c). The organizers continued:

That is why this year, we are calling on Pacific Warriors to voyage with us to Australia, to show that there must be limits to how much coal they dig up. Warriors will take traditional canoes made in the Islands and deliver these, in a colourful and energetic display, to major supporters of the fossil fuel industry. We will show the fossil fuel industry that Pacific Islanders will fight peacefully to protect their cultures, their homelands and their oceans. $(350$ Pacific 20I4c)

Participants worked to secure additional seaworthy vessels to transport at least twenty people from their home islands to Sydney in SeptemberOctober 20I4 (350 Pacific 20I4b). Videos documenting the Canoe Building Day of Action are available on YouTube. Although the ultimate outcome of this chapter in 350 Pacific's story has yet to be seen, the journey is impressive and meaningful in its own right.

Another project with plans to voyage across the Pacific and beyond is the multimedia dramatic performance Moana: The Rising of the Sea, which is slated to tour internationally in 2014-20I5 (Miller 20I4, 587). Born out of a desire to show the human face of climate change, Moana: The Rising of the Sea tells the story of the fictional island Marawa, which 
is consumed more and more by the sea as the drama unfolds, instilling increasing fear in the Marawa community. This echoes the experiences of real-life communities across the Pacific region, such as Fiji, Kiribati, the Marshall Islands, Niue, Sāmoa, and Solomon Islands, all featured in the production. The creative team has combined music and dance from several Pacific Island cultures, choral singing, opera, ballet, modern dance, and aerial dance to dramatically illustrate the deep connections Islanders have to their islands and the immense fear and heartbreak they feel at the thought of losing them. This whole-toolbox approach to creative expression-making use of an array of available cultural and artistic resourcesacknowledges the lived experiences and artistic worlds of contemporary Islanders, who come from and participate in complex and diverse communities, and reflects the philosophy of inclusiveness and artistic freedom that lies at the root of the Oceania Centre for Art, Culture and Pacific Studies at USP (see Hereniko 2006).

The production grew out of the recent establishment of the European Consortium for Pacific Studies (ECOPAS), "a multidisciplinary project designed to provide coordination and support to research and policy communities on issues connected to climate change and related processes in the Pacific Islands region, in order to define better options for sustainable development" (ECOPAS 20I4). Hosted by Pacific research centers at four European universities (Universitetet i Bergen in Norway, Aix-Marseille Universite in France, the University of St Andrews in the United Kingdom, and Radboud University Nijmegen in the Netherlands) and by two major Pacific institutions (the University of the South Pacific in Fiji and the National Research Institute in Papua New Guinea), "it is the first-ever network to develop extensive, durable collaboration between European and Pacific scholarly institutions, as well as between research institutions and local, national and international political agencies" (ECOPAS 20I4).5 According to ECOPAs Coordinator Edvard Hviding, Moana: The Rising of the Sea "is destined to become a fountain of inspiration from which new initiatives of scholarship, activism, policy, education and culture will follow. The ECOPAS agenda that we share realizes its full potential for creating understandings at the crossroads between the local and the global precisely as the drama of Moana unfolds and reminds us of what it means to be human" (ECOPAS and USP 2OI3b).

All three projects show Islanders' dedication to climate-change awareness and their refusal to remain dormant as the sea reclaims their lands and cultures. The following analysis of these projects comprises four core 
sections. In the first section, I use Robert Melchior Figueroa's concepts of environmental identity and environmental heritage to articulate the complex relationships Islanders have with their environments that make climate-change action imperative. In the second section, I consider the role that Christian faith plays in Islander responses to the news that their islands are in danger. In the third section, I discuss the final scenes of Moana: The Rising of the Sea to acknowledge the immensely painful reality of change and loss that Islanders may face both now and in the future. In the fourth section, I examine examples of how Islanders and their nonIslander allies are fighting to make Islander voices heard, renegotiating identity through the performance of war challenges, songs, and dances. While the news media tend to identify the Pacific Islands as tiny flecks of land in the middle of an expansive ocean and their people as "tragic victims" of climate change, participants in climate-change awareness efforts like Water Is Rising, the Pacific Warrior Campaign, and Moana: The Rising of the Sea are constructing an identity of unity and empowerment. They thus erupt in song and dance to proclaim their pride in culture, celebrate their faith in God, share their fears for the future, and declare their refusal to be identified as anything less than fighting.

\section{Environmental Heritage}

To Islanders and other indigenous peoples, there is much at stake in the war against climate change, as Brij V Lal, Joakim Jojo Peter, and Patricia Cochran and others have explained:

Place matters. It gives us identity, shapes our imagination and experiences, and informs our understanding of the world around us. It is both matter as well as metaphor, a source of material as well as of cultural and spiritual sustenance.... It connects us to time and locality, perhaps even to life and death. (B Lal 2004, I)

Islanders need to belong to places, the physical plots, taro fields, coconut groves, sandy beaches, portions of reefs, fishing corals, and the island in general... If there is a frightening notion that most islanders share, it is the concept of being lost, being out of place, or the inability to make connection with a place. (Peter 2004, 26I)

Native cultures and sense of identity are directly tied to the places where people have lived for generations through observations, riddles, stories, dances, art, language, music, and traditions.... Since each cultural element evolved 
in a climatic and ecological context, it is vulnerable when climate alters that context and as elder knowledge-keepers pass away. (Cochran and others $2013, \mathrm{np})$

All of these assertions exemplify Robert Melchior Figueroa's concepts of environmental identity, "the amalgamation of cultural identities, ways of life, and self-perceptions that are connected to a given group's physical environment," and environmental heritage, which "pertains to the meanings and symbols of the past that frame values, practices, and places people wish to preserve as members of a community" (20I I, 233). Peter's need for connection to the land and features of an island-a particular type of environment-is an expression of his specific environmental identity, which he in turn ties to his and others' more general Islander identity. Similarly, the songs and dances that describe and sometimes enact interactions with the island environment (such as fishing songs) and the costumes that are crafted out of island resources all contribute to Islanders' environmental identity. Cochran and others, though referring to indigenous peoples in Alaska, have aptly noted that all such things are often deeply rooted in the past and cultivated over time, thus making them part of a people's environmental heritage. Indeed, Figueroa elucidated, "Environmental heritage is the expression of an environmental identity in relation to the community viewed over time" (20II, 233). Climate change affects a community's environmental identity and environmental heritage because it threatens the very physical features and resources that sustain them (Figueroa 20II, 233).

During a Water Is Rising panel discussion titled "Science and Art in a Climate of Change: A Dialogue of Nations," held at UCLA on I3 October 2OII, all three of the delegations' representatives stated very clearly that they do not want to lose their lands because their cultures, identities, and environments are intimately connected to one another. Maiava explained, "Losing a home, I can assure you, is not the same as losing a land. Losing land is losing culture, losing your identity, losing almost everything that is dear to you" (UCla 20Ira). Francis Tebau, Te Waa Mai Kiribati's representative, added, "If we lost our land, just like my brother from Tokelau says, we lose everything: our culture, skills that we have, everything" (UClA 20I Ia). Finally, Andrew Semeli, the representative for Pa Laumilo, poignantly stated:

We love our cultures, we love our traditions, and we are connected to our land ... [to audience] and I know that you also love your land. You don't want 
to lose your land. You don't want to lose your culture and your traditions. [pause] Likewise. We also don't want to lose that. (UCLA 20I Ia)

The participants of all three awareness projects have been very straightforward about the fact that they and their cultures are intimately connected to their islands and that the loss of those islands means the loss of their entire environmental heritage. In the following three discussions, I focus on how Islanders have displayed this environmental heritage and emphasized its importance through songs and dances that showcase the material culture and related lifestyles of the atolls represented in Water Is Rising, through a scene in Moana: The Rising of the Sea that highlights Islanders' belief in the interconnectedness of all, and through two separate presentations of a Kiribati song and dance that reveal Islander reinterpretations of a national environmental symbol in the new context of climate change.

\section{Expressions of Pride in Material Culture}

Despite the importance of environmental identity and environmental heritage, the major, active role that the natural environment plays in culture is often overlooked. Paul D'Arcy explained, "In most books and articles the environment is relegated to the general introduction that outlines environmental and cultural structures to set the stage for the human drama that then unfolds" (2006, I 2). But in the Water Is Rising tour, the Pacific Warrior Campaign, and Moana: The Rising of the Sea, the environment was and is very much a part of the drama, as featured in the song texts, in the costumes made out of natural materials, in the dancers' movements, and in the choice of characters.

One could argue that all of the songs and dances presented in these performance contexts reflect the participants' environmental heritage because they originated and were further shaped in the island environment (Cochran and others 2013, np), but some of the pieces overtly express the performers' connection to the land and the materials and lifestyles it sustains. For instance, while several of Kai Te Gali Mai Nukunonu's pieces in Water Is Rising reference fishing and sailing, two stand out for their specific attention to Tokelau material culture and related cultural activities. "Tutuga Pa Taku Tiwha," a fishing song, recounts the importance of mother-of-pearl in Tokelau culture. As the online program notes explain, "6 "mother-of-pearl is one of the most valuable items in our culture. Pa matua is the mother-of-pearl pendant that a father gives to his daughter 
as a symbol of beauty and cultural values which she wears on her wedding day and other special occasions. Some of the cut pieces are also used to make special hooks to cut tuna and for lures to catch different fishes" (Water Is Rising 20IIb). The song text describes cutting the mother-ofpearl, which must be done carefully due to the importance of the resulting items for the life and culture of the people, and then it refers to the traditions involved in fishing for tuna. Another Tokelau piece, "Toku Koa" (meaning "my precious"), "is about the valuable materials and handicrafts unique to Tokelau" (Water Is Rising 20I Ib). In a video of the Water Is Rising performance at UCLA, the men display miniature woven mats, each approximately one square foot in size, while the women dance, each wearing a pa matua around her neck. The translation provided in the online program notes reads as follows:

Our precious protector Hemoana ${ }^{7}$

Bestowed upon us the raw materials

To decorate our island and make us beautiful.

Let Tokelau be known to the world,

Through her precious arts and crafts.

We are proud, we are proud. (Water Is Rising 20I Ib)

As the translation of "Toku Koa" reminds us, all of the groups proudly display the material culture of their islands in the costumes that they wear onstage. Te Waa Mai Kiribati's piece “Te Kabuti," for instance, highlights the use of coconuts in Kiribati life, though it does not mention them specifically, through the coconut-frond skirts that the women wear for the dance. The online program notes describe the skirt and explain how this important item created from the environment is used to convey the meaning of the song: "The black Kiribati coconut frond skirt is very difficult to make and even more difficult to dance in. The dancers' movement of the black illustrates the dynamic motion of the Kiribati canoe as it travels far and wide. Feminine power is expressed through the control and energy of the dance and song" (Water Is Rising 20I Ib). Without the coconut fronds, not only the costumes but also the meaning of the song would be drastically altered.

\section{Understanding Interconnectedness}

Islander environmental identity and heritage extend beyond the material to include notions of spiritual, relational, and ancestral interconnectedness with the environment. As Kara Miller explained in her review of the 
premiere of Moana: The Rising of the Sea, "Primarily told in a dialogue between movement, projected image, and song, this poetic story embodies the ecological notion of unity. In our bodies, islands, ocean, sky, and planet, in our being, we are one body, interconnected" (20I4, 586). Such a holistic understanding stands out, for instance, in the decision to make features of the environment-such as the ocean and a tree and her spiritactive characters in the production and serves as the focal point of the aria of the Vesi Loa tree.

Before the aria begins, a slide on the screen reads, "To build a canoe, a tree and its spirit must be sacrificed" (ECOPAS and USP 20I3a). Marawa Islanders seated and standing around the Vesi Loa tree, which is initially represented by a tall, thin sheet of brown fabric, perform a song and dance honoring her. After this, the Vesi Loa comes to life, the fabric opening to reveal a young woman draped in a majestic brown gown, with tall, leafy branches extending from her hands and her head. Emerging slowly, as if carrying in her branches the weight of the world, the Vesi Loa begins to sing of deep time, deep love, and that which she is destined to do: "I give my life to generations to come. / The sacrifice is mine" (ECOPAS and USP 2OI3a). Above her, an aerial dancer-her spirit-moves gracefully to her song, while Marawa Islanders respectfully remove her branches and prepare her for her final moments, passing the branches along with great care to others nearby. As the aria ends, the Vesi Loa reaches out and grabs the hand of the spirit above her while the men lift her up and carry her away, the sound of a falling tree echoing through the space. The Marawa Islanders then close the tree-felling ceremony with another song and dance.

As this description clearly conveys, the Vesi Loa tree is a pivotal character in the story. Her sacrifice ensures that the Marawa Islanders will have a sturdy canoe for the activities that sustain them and for safe departure from the island should such a journey be necessary in the future. Such relationships between Islanders and their environment are celebrated throughout the Pacific Islands, perhaps most notably in songs and dances and other forms of creative expression, and it is no surprise that it is to these forms of expression that Islanders often turn to make sense of and raise awareness about current events. "Performative arts," suggested Hviding, "are an essential part of all major proceedings in the Pacific, and provide a particular sharp focus on how Pacific Islanders view the challenges of the day" (quoted in Drønen 20I3). 


\section{Reinterpreting a National Symbol}

According to Mitoma, there was no climate change-specific song and dance repertoire in Kiribati, Tokelau, or Tuvalu before the start of the Water Is Rising project, but there was one piece in Kiribati that the people have reinterpreted in the context of climate change (pers comm, I3 July 20I3). "Koburake," composed in I978, tells the story of a frigate bird that is unable to find Kiribati on its return home and therefore calls the land to rise up from the depths of the sea (Republic of Kiribati Delegation 2009). An important part of Kiribati's environmental heritage and the country's national bird, the frigate, which flies above the setting sun and ocean waves on the country's flag, "symbolizes many important things in the traditional living context of the I-Kiribati. It provides navigation to fishermen while lost at sea, provides weather information for the people and also gives a sign of peace and harmony" (KNTO 20I3). Importantly, the bird is embodied in Kiribati dance. As Mary E Lawson Burke has noted, ruoia, indigenous Kiribati dances like those seen in both Water Is Rising and Moana: The Rising of the Sea, include "choreographed sequences of flowing movements, interspersed with poses and abrupt movements of head, hands, and arms. ... . [that] are based on actions of birds, fishing, martial arts, sailing, and canoes" (I998, 76I). The Kiribati National Tourism Office similarly explained, "The movement of the feet, hands and of course the whole body imitates the movement of the frigate birds while walking and flying" (KNTO 20I3). The very moving song "Koburake" has been used in at least two climate-change awareness campaigns: the I 5 th Conference of the Parties to the United Nations Framework Convention on Climate Change (COP I 5), convened in 2009 in Copenhagen, Denmark, and the Water Is Rising tour. Differences in song structure and delivery between the two presentations reveal how I-Kiribati have reinterpreted the frigate's song in the context of climate change.

At COP I 5, the Kiribati delegation closed a side event on 9 December with a brief video. The clip, posted to YouTube the same day, presents "Koburake" along with footage of the islands, the ocean, the primary singer, and a frigate flying all alone. ${ }^{8}$ The narrator explains that though the piece was written before the people knew anything about climate change and its effects, "this prophecy from the past reminds us of the uncertain future we face as a country and as a people" (Republic of Kiribati Delegation 2009). "Koburake" is presented in the video without dance, and the 
diatonic melody is sung by a young woman who is joined at times by two to three other youths (not shown) harmonizing in the thirds or fifths that Burke described as occurring in Kiribati dance music (1998, 76I). ${ }^{9}$ There is minimal ornamentation, and the material is repeated with only slight variation in the melody. ${ }^{10}$ The translated text presented in the video consists of five sections, the fourth and fifth nearly identical, with thematic material as follows:

Section A: The bird longs for home and calls its name, but it cannot find Kiribati, so it asks Kiribati to hear its song.

Section B: The bird laments being all alone with no one to help.

Section C: The bird calls Kiribati to rise up out of the deep ocean so people can see it from afar.

Sections D and E: The bird calls again for Kiribati to rise up.

[D: "Koburake Kiribati” (x2); E: "Mwemwe Kiribati” (x2)]

(Republic of Kiribati Delegation 2009; Water Is Rising 20I rb; UCLA 20Irb)

The overall song structure involves a repeat of the first three sections. Section D concludes the first delivery, and E closes the second to yield the following form:

ABCD ABCE

The song is deeply moving, and the closing footage strengthens its powerful message: we see a sprouting coconut-with the Kiribati flag in place of the sprouting leaves-floating alone on the ocean.

During the Water Is Rising performances, the Kiribati group presented the same piece, this time including the dance. In the UCLA video, the piece begins with an empty stage except for a backlit, net-covered scrim on which a PowerPoint presentation with translations and images from the islands is projected. The song leader calls out from the wings, and he and two others (male and female) begin singing, the leader providing an elaborate variation that soars above the melody delivered by the other two. Singing, the entire troupe either walks or dances onto the stage in single file, the dancers mimicking the flight of the frigate bird. Ultimately, the group configuration is eight dancers, four women in the front row with four men behind; the three singers standing behind the dancers in the gaps between the columns, with the woman in the middle spot; and one man at the very back center deferentially holding the Kiribati flag. Halfway 
through the song, the two rows of dancers swap places as the men move to the front.

The order and delivery of the text and its thematic content in the Water Is Rising performance are different from that in the COP I 5 video, though the two versions are otherwise very similar. Using the same thematic breakdown provided above, the overall structure of the UCLA Water Is Rising performance is:

\section{ACD B ACE}

Even though the B section has a central location in this structure, it is only performed once, so its prominence is far diminished compared to that in the COP I 5 structure. Thus, less emphasis is placed on being alone with no one to help. Indeed, even the vocal delivery in the Water Is Rising performance moves away from loneliness, save for a brief moment of text painting in section B:
A: trio
C: leader (rise up) / group (pull yourself up so people can see you from afar)
D: group

B: leader (all alone) / group (with no one to help)
A: trio
C: leader (rise up) / group (pull yourself up so people can see you from afar)
E: group

Only three segments in the song are delivered solo: the command "koburake" (sung twice) and the lament that one is all alone. In the cop I 5 presentation, however, most of the first appearance of the text is delivered solo, with a second voice joining in at the end of section $\mathrm{C}$ and for all of the brief section D. The second appearance includes one to three additional voices for all but section $\mathrm{A}$ and the last part of section $\mathrm{E}$, but there are no large group sections. To a non-I-Kiribati observer, these differences stand out: the version of the song in the COP I 5 video comes across as a heartbreaking lament, with only the footage at the end breaking the sadness and asserting resilience, while the Water Is Rising version reverberates with energy and hope because of its seeming downplaying of the frigate's loneliness. 
While the two performances vary in terms of delivery and therefore evoke different emotional responses from the audience, the overall message of resilience in the face of climate change is the same. The call to rise up resounds throughout the Water Is Rising version and emerges in the closing footage of the COP I 5 video, despite the earlier emphasis on the frigate's sadness. The sprouting coconut of Kiribati-reminiscent of the spread of life through the islands and of the olive branch-carrying dove in the story of Noah and the Ark-is a very powerful symbol of Islanders' insistence that they will prevail.

\section{"DeEp FAith"}

Many Islanders' emphasis on faith while grappling with the implications of climate change is not surprising given Christianity's significant role in the Pacific, which dates back to the arrival of the first missionaries in the region in 1797 (Garrett 2000). Although the topic of evangelization in the Pacific is contentious, Jane Moulin explained that

most Pacific people frame conversion as Islander agency and staunchly defend evangelization as a dynamic process in which Islanders actively chose to embrace Christian teachings. In villages across the Pacific, the Church commands a place of respect as the central institution in religious and social life and one to which Islanders willingly commit their spiritual lives, voices, time, and money. (Diettrich, Moulin, and Webb 20I I, 69-70).

Mitoma believes, however, that this dedication to the Church has led to some difficulty in raising climate-change awareness in those communities (pers comm, I3 July 20I3). Though governments may be very vocal about the reality of climate change, many ministers do not believe in it and tend to have the power to influence local beliefs and opinions on the topic. ${ }^{11}$ This situation has appeared in documentaries such as There Once Was an Island and the Tagata Pasifika special episode "Toku Fenua Ka Galo," which detail the effects of climate change and related social and cultural issues in Takū and Tuvalu, respectively (March 2010; Utanga and Stehlin 20I0). In There Once Was an Island, the villagers are torn as they try to decide what they should do in the face of coastal erosion and damaging king tides, both of which are tied to climate change. Some wish to leave, some wish to stay, and some believe that God already knows about the problem and will save them-a view that is criticized by others in the video as foolish (March 2010). Marshallese poet Kathy Jetnil-Kijiner referred to this issue as well in her spoken-word piece "Tell Them": "tell them that 
some of us / are old fishermen who believe that God made us a promise / some of us / are more skeptical of God" (20II). ${ }^{12}$ Kiribati President Anote Tong also addressed such beliefs during his 20I4 East-West Center presentation, using a story to plead the case for action: An old woman stays behind during a flood, waiting for God to save her. Three times she turns down assistance from rescuers, and when she eventually drowns and goes to heaven, she asks why God never saved her. God replies, "I tried to save you three times, but you wouldn't come” (Tong 20I4). Other faithbased beliefs come into play in the face of climate change as well. "Toku Fenua Ka Galo," though acknowledging the importance of Christianity in Tuvalu, describes many of the deeply religious as skeptics because they do not believe that God will send another flood and are therefore not worried about climate change (Utanga and Stehlin 2010). As Mitoma explained, however, if people were to think constantly about their islands disappearing in their day-to-day lives, they would become "mental basket cases"; instead, they have to have a "deep faith that things are going to work out" (pers comm, I3 July 20I3). This deep faith is therefore an important tool that some Islanders use to understand the very difficult situation that their communities face.

The entire Water Is Rising performance is framed by and filled with expressions of Christian faith-from the event's introduction, which features all three groups performing separate pieces simultaneously, to its unified finale. Six out of the twenty-nine pieces listed in the event's online program notes specifically mention God, most offering up praise or asking for mercy (Water Is Rising 20Iгa). Two of the pieces performed by $\mathrm{Pa}$ Laumilo stand out because they convey the complexity of this issue in the group's own community in Tuvalu. The first piece, "Siki Atu Te Fakafetai," is a celebratory piece in which the performers thank those who are present (called "brothers and sisters"), declare their faith in God, and ask that people remember their land. One section of the translated text asserts, "So many things happen to us, / But we believe / God will never forsake us. / In times of trouble, / He will always be there. / He will provide his abundant love / So we can live happily" (Water Is Rising 20Ira). The next piece, "Atu Lalolagi," reveals seemingly conflicting views regarding climate change. The translated text at first says, "Worried about climate change, / My Tuvalu, what will happen?" but then later states, "Small and low in the Pacific, / We do not panic with climate change. / Looking back on God's word, / His rainbow shines forever" (Water Is Rising 20гіa). Notable in this is the reference to the rainbow, the token of God's cove- 
nant with Noah and all creatures that God will never again send a flood to destroy all living things (Genesis 9:I 2-I7). Both songs thus highlight the importance of faith and belief in God's benevolence for Christian Islanders, even when fearing for the future and asking for help.

A compelling request for help comes at the end of the event, when all three groups take to the stage to perform the finale, "Te Aliki E Alofa Mai La." Led in the UCLA performance by Pa Laumilo-with an all-cast chorus and accompaniment by two guitars and an 'ukulele-the hymn asks for God's mercy and salvation: "Have mercy and take care of me / Until your peaceful paradise" (Water Is Rising 20 I Ia). In the video of that performance, the song very smoothly transitions into the hymn "Amazing Grace." Thus, the event was sealed with a very powerful message of faith-one easily recognizable to most in attendance because of the inclusion of the widely known Christian hymn. More than simply a creative way to close the show, the finale served as a reminder to all that helpwhatever the source-is desperately needed. While the emphasis in Water Is Rising was on Christianity due to its significance to the particular performers and communities involved in the production, it is important to stress that moral responsibility to mitigate climate change as well as empathy for those affected extend well beyond Christianity to include people of all faiths and affiliations.

\section{When the Flood Does Come}

As the negative effects of climate change intensify, a sense of imminent danger grips Pacific communities across the region. Moana: The Rising of the Sea skillfully portrays this context, celebrating Pacific Island cultures while revealing the strong emotions and fear that Islanders feel as they watch the sea rise. As the opening monologue, Jetnil-Kijiner's poem "Tell Them," performed by Sinu Naulumatua, implores:

tell them about the water

how we have seen it rising

flooding across our cemeteries

gushing over sea walls

and crashing against our homes

tell them what it's like

to see the entire ocean_level_with the land

tell them

we are afraid (Jetnil-Kijiner 20I I; ECOPAS and USP 20I3a) 
Moana: The Rising of the Sea not only tells them, it shows them. In the final scene, frigate birds-no longer the measured and majestic symbols of peace and harmony celebrated in Kiribati dances but instead hauntingly vigilant messengers-warn the Marawa Islanders of impending danger (ECOPAS and USP 20I3a). As they arrive, the Islanders onstage take heed, singing an operatic piece marked by falsetto voices and staccato phrases reminiscent of grandiose Hollywood battle scenes. Dancers dressed in dark blue-green bodysuits with fine black netting across their shoulders arrive one by one. The music changes to rhythmic patterns played on log slit-drums, and the dancers leap, circle, and swoop in a carefully choreographed frenzy, contorting themselves as if mimicking the angular profile of the frigate bird in flight: bodies bent forward at the waist and arms forming inverted Vs at their sides. Each face scans the horizon. The flood has come.

After much conflict, the Islanders decide to leave Marawa. They prepare their vessel and gather items of great value to their community to take with them: woven mats, tapa, fiber cordage, a coconut, papayas, taro, a kava bowl, and more-all pieces of material culture with ties to the island environment and the way of life that it has sustained for generations. ${ }^{13}$ Describing the entire situation, Hereniko explained: "The final scene follows from the beautiful dances and music from the different islands so when juxtaposed, one realizes the enormous loss of culture (dance and music particularly) when everyone and everything goes under. It isn't just the people going under, but also the loss of oral cultures, a loss to the whole world" (pers comm, 23 June 20I4). The effect is powerful. In Miller's words, "At the close of the premiere performance, I looked around the theater and saw many people crying. The response of one audience member whom I spoke to about her experience of the performance was, 'This is real.' There were no more words, only tears" (20I4, 587). Indeed, a publicity piece on the production stated, "It is ... so powerful in its depiction of the human impact of climate change that some Pacific negotiators remarked that they could perhaps have pushed international climate talks further had it been shown at meetings" (European Commission 20I4).

Having to leave one's homeland as depicted in these final scenes is nothing new for Island communities, who celebrate a rich history of navigation and settlement and consider environmental changes part of that history and their cultural knowledge. According to Hviding, Sverre Ole Drønen reported, "this explains a certain stoicism and pragmatism found in the various island cultures. People are simply used to having to take to the 
ocean and resettle elsewhere. However, the challenges currently posed by global warming are greater than anything even these resilient islanders or their ancestors have ever had to face, and given the nation-state structure of today there are few alternative places to settle for displaced islanders" (Drønen 20I3). Indeed, the rate and extent of environmental change and the social, cultural, economic, and other implications for the region and the world are unprecedented. This makes action to mitigate and adapt to the negative effects of climate change all the more crucial. But in order for there to be action, Islanders and their allies must find a middle ground between the belief that everything will be okay and the fear that there is no hope left. It is this delicate balance between vulnerability and strength that marks the warrior identity that Islanders are negotiating for themselves: a warrior knows the dangers he or she must face but refuses to back down.

\section{"We Are Not Drowning. We Are Fighting"}

Carol Farbotko, discussing representations of Tuvalu and climate change in Australian media, has argued that the status of "'tragic victim' ... marginalizes alternative discourses of adaptation for Tuvaluans and other inhabitants of low-lying islands, and silences alternative constructions of Tuvaluan identity that could emphasize resilience and resourcefulness" $(2005,280)$. Similarly, Anna Majavu has explained in reference to Western journalistic representations of climate change in the Pacific that "talking about 'disappearing nations' was disempowering and did nothing to help the more useful idea that people must adapt to climate change" (2OI4). For the participants in Water Is Rising, the Pacific Warrior Campaign, and Moana: The Rising of the Sea, however, silence is not an option (UCLA 20IIa; 350 Pacific 20I3 3; 350 Fiji 20I3; ECOPAS and USP 20I3a, 20I3b). All three projects have provided opportunities for ordinary Islanders to make their voices heard through songs, dances, and other elements that highlight their pride in their cultures and their determination to overcome climate change. One powerful way that participants in Water Is Rising and the Pacific Warrior Campaign's Warrior Day of Action renegotiated their identities vis-à-vis climate change was through the presentation of war challenges, songs, and dances, becoming a sea of warriors rising up together to protect the lands and cultures that they cherish.

During the Water Is Rising performance at UCLA, Maiava told the audience, "When we see a problem, we like to make a solution" (UCLA 20 I Ib). To great applause, he then shared the news of Tokelau's renewable energy 
plan: setting an example for the entire world, Tokelau has become the first nation to become roo percent reliant on renewable energy sources (New Zealand Aid Programme 20r2a, 20r2b). "Our land might be small," he continued, "but we have the biggest heart to fight our cause. And I present to you the warriors-that represent all the people of Tokelau-that's going to do the war dance" (UCla 20IIb). That war dance, "Tui Kamilolo E," announces the arrival of an unknown canoe and calls the warriors to prepare for possible battle (Water Is Rising 20IIb). Following the aesthetics of Tokelau performance, in the UCLA video, the text is delivered three times with ever-increasing intensity. During the first delivery of the text, the dancers (all men; the women are seated) remain stationary and with no lower torso or leg movements as they enact the carrying of a canoe and other actions with their upper bodies. In the second and third deliveries, they include their lower bodies in the dance, lowering their stance as they increase their overall volume, tempo, and fierceness. This is all driven by the pōkihi, a wooden box drum approximately two feet wide, three feet long, and one foot tall that is played with the hands, and an $a p a$, a cabin bread tin drum that is played with two drumsticks. Each instrument is played by one man using rhythms typical of Tokelau music (see Thomas 1996; Steiner 20I2). Kai Te Gali Mai Nukunonu then concludes the piece with a brief ending dance, also characteristic of Tokelau performances. This use of warrior imagery in Water Is Rising was powerful, and it extended well beyond that particular awareness campaign.

A very similar war dance, this time explicitly referring to the rising sea, appears in a video that Maiava posted on YouTube of the Tokelau events for the multi-island Warrior Day of Action. According to the movement's website, the entire population of Nukunonu Atoll participated (350 Pacific $203_{3}$ ). The dancers (again all men) stand thigh- to hip-deep in the ocean on the lagoon side of the atoll, pushing forcefully through the water in order to execute the dance movements. Behind them, on two poles planted in the sand beneath the water, is a banner with the event's slogan: "We are not drowning. We are fighting" (Maiava 20I3). Though the video clip Maiava posted is very brief, viewers can still easily apprehend the powerful message that the event was designed to promote and convey.

The Fiji participants in the Warrior Day of Action similarly used the ocean as a stage in the short film Maroroi Vuravura, which features a Fijian na bole (warriors' challenge) of the same name, composed and choreographed by Manoa Rasigatele (350 Pacific 20I3c). Meaning "protect the earth," Maroroi Vuravura "showcase[s] that Fijians are proud, resil- 
ient and determined, and together can be proactive at meeting climate change impacts as they happen and can build a movement that can create climate change solutions the Fiji way" (350 Fiji 20I3; 35 O Pacific 20I3c). In the film, young men and women who are going about their daily lives in twenty-first century Suva are called by a conch-shell signal to abandon their activities, prepare for battle, and head to the shore. One of the men says, "We are not drowning," and a woman immediately follows with, "We are fighting." As more warriors arrive in ceremonial dress, they take their positions at the water's edge, the waves crashing past their legs to extend its reach farther inland. The leader calls out a challenge in Fijian, which is translated in the subtitles as, "Listen to me! / Climate has changed. / You ... me / Let's unite! / Are you ready?" The warriors reply, "Yes!" They all then take a firm stance and begin the newly composed na bole, which recounts the damage caused by climate change; declares the warriors as the children of Fiji, the ocean, and the canoe; and summons Fiji to take action. The final words very clearly announce the participants' warrior identity: "I am the ocean warrior. / Fiji, don't be silent, / speak up! / Let's save the earth today / for the children of tomorrow." The video concludes with a statement of 350 Pacific's slogan, "Io० percent possible with you!" (350 Fiji 20I3).

Such warrior challenges are important because they show that Islanders are declaring war against climate change and that it is not just Islanders from low-lying atolls who are intent on fighting-it's everyone who feels that climate change must be stopped. Thinking of the Pacific Islands as isolated specks of land in the middle of the world's largest ocean encourages the belief that their inhabitants will inevitably succumb to climate change. But, as Hau'ofa argued, Oceania simply does not work that way. The initiatives of Islanders and allies from low atolls and high islands alike, along with individuals and organizations outside the region, evince the interconnectedness that is the basis for viewing Oceania as "a sea of islands" (Hau'ofa 2008, $3 \mathrm{I}$ ).

\section{Conclusions: Fighting Together on All Fronts}

The Water Is Rising tour, the Pacific Warrior Campaign, and Moana: The Rising of the Sea all show Islanders' dedication to climate-change awareness and their refusal to watch in silence as their islands disappear. Figueroa's concepts of environmental identity and environmental heritage are helpful for articulating the complex relationships between Islanders 
and their environments, relationships that compel them to take action. Action through the songs, dances, and other features of the three performative campaigns discussed in this essay demonstrates visible and audible examples of Islander pride in environmental heritage. Moreover, the aria of the Vesi Loa tree from Moana: The Rising of the Sea highlights Islanders' holistic understanding of the world around them and their place in it, while both the COP I 5 and Water Is Rising versions of the Kiribati piece "Koburake" show how I-Kiribati have reinterpreted the song of the frigate bird in order to raise awareness of climate change and to announce the resilience of the people. Resilience comes in many forms, and through all of these performance contexts, we can see Islanders responding to climate change both with deep faith that things are going to work out and with action in order to make sure that they do.

All of these elements, however varied, came together in Water Is Rising, the Pacific Warrior Campaign, and Moana: The Rising of the Sea as messages that Islanders have chosen to share with their immediate audiences and with the world. Moving away from outside representations of Islanders as mere victims in a far and rising sea, they have come to embrace their own identities as warriors with the power to rise up against climate change. These events were not isolated campaigns but rather parts of a larger movement to raise global awareness of the destructive impacts of climate change in the Pacific region, to make Islander voices heard and their human faces seen in order to encourage support from beyond the region for mitigation and adaptation efforts (Lee 20II), and to announce firmly to the people of all nations that Islanders are prepared to stand together to face this challenge.

As has been emphasized in and through the campaigns, Islanders' strength does not come from individuals taking on the warrior identity alone but rather from the combined efforts of an entire sea of warriors. Each person and each school of knowledge has something vital to contribute to the fight, much like each member of a community has something to contribute to the building and sailing of a canoe. As Fenton Lutunatabua of 350 Pacific explained, "Building a canoe usually involved the entire community. While there was segregation of roles (men made the hull and rigs, women made the sails), the entire community—men, women, young people and elders-came together to make the rope and cord that bound the craft together" (2OI4). Without the participation of the entire community, the canoe would not be complete: the absence of any part could render the vessel unusable, and the absence of skilled and knowledgeable 
sailors could make a successful voyage unlikely. On a global level, we must recognize that it will take all of our diverse skills, knowledges, experiences, and resources to put an end to the threat that plagues the Pacific and the world. Referring to such a fusion of efforts, Hereniko has suggested that "maybe there is a way out of what appears to be an inevitable outcome. Maybe the solution to our survival lies in western science marrying indigenous knowledge. Maybe, like a double-hulled canoe, western science and indigenous knowledge will safely navigate us out of these dangerous waters? This is the hope of Moana: The Rising of the Sea" (ECOPAS and USP 20I3 b). It will take fighting on multiple fronts to win this war. The performing arts, like the projects discussed here, are crucial, for as Hviding has argued, "it is in the performative arts that we meet the most immediate, most powerful expressions of how Pacific ways of life are threatened by rising seas, dying reefs, and extreme weather" (ECOPAS and USP 20I3b). To Hereniko,

the arts have an important role to play regarding issues of concern in the community. This would be the area of feeling and emotion, and I wanted to be part of a project in which art (music, dance, drama, in this instance) could contribute to the conversation on climate change. And I felt that there is a lot of scientific data available, but very little on the human dimension of climate change. How does it feel, for example, to be forced to abandon all that you hold dear in your homeland because of sea level rise? Under such circumstances, people sometimes respond emotionally and irrationally, and not necessarily in a logical or rational way. This is what I felt was missing in the debate on climate change, and Moana was intended to fill this gap. . . . It moved understanding of the effects of sea level rise from the head to the heart. (pers comm, 23 July 20I4)

Finding different ways to tell the story, then, is key. As Jetnil-Kijiner shared while discussing her process for choosing a poetic medium, "In the end, my big question when writing isn't always 'Should this piece be a page poem or a performance poem?' Most of the time, my only question is, 'How should this story be told?'" (2OI4). In a similar way, the story of climate change, which definitely needs to be told, must not be limited to any one field, any one medium.

In closing, I return to the UCLA Water Is Rising panel. As each group's representative tearfully explained, Islanders love their land, their cultures, and their traditions, all of which are intimately connected to one another. Because of this, to Maiava and surely many others, "the thought of losing your land is like a nightmare" (UCLA 20I Ia). The participants in Water Is 
Rising, the Pacific Warrior Campaign, and Moana: The Rising of the Sea have displayed through their song and dance performances the rich environmental heritage that their islands have nurtured, they have expressed what it would mean to lose that heritage and those islands, and they have called on all the world to work together to prevent further loss. These performance initiatives, however, make up just a small sample of the many diverse responses to climate change that Islanders have and continue to put forth, and this dialogue piece represents only one way of telling one part of that story. It is my hope, then, that this contribution-both its content and its gaps-will inspire others to engage in ongoing discussion and to tell stories that involve perspectives, initiatives, issues, and ways of knowing and telling that this one piece, this one author could not cover. The UCLA Water Is Rising panel, which included brief performances by Te Waa Mai Kiribati, Kai Te Gali Mai Nukunonu, and Pa Laumilo, concluded with a Tokelau piece (a hiva hahaka) that ended with the exclamation "O fanatu e!" (UCla 20IIa). An apt statement for the end of the meeting, for the tour overall, and for this paper, the phrase, characteristic of many Tokelau performances, means, "We have given, now we pass it to you” (Betty Ickes, pers comm, 30 Jan 20I2).

I wOUlD LiKe TO THANK Vilsoni Hereniko and Judy Mitoma for sharing their time, perspectives, and experiences with me; Jane Moulin for her unwavering support and valuable feedback during the development of this piece; Jan Rensel for her impeccable attention to detail and mentorship; and two anonymous reviewers for their thoughtful and tremendously helpful comments on an earlier draft of this piece. I also extend my deepest gratitude to all of the artists and other individuals involved in the initiatives discussed above, without whom this piece would not have been possible, and to my parents, without whom I would not have been possible. Any errors in this work are my own.

\section{Notes}

I For a comprehensive look at the general implications of and debates surrounding climate change, see Dryzek, Norgaard, and Schlosberg 20Iг. For reports and studies on the specific effects of climate change in Pacific Islands, see Aalbersberg and Hay 1992; Dix 20II; Ereth 20I2; Fedor 20I2; Lazrus 2009; McLean and d'Aubert 1993; Oxfam 2009; Sem and Underhill 1992; Sullivan I99I; and Urbano and others 2010. 
2 For this essay, I have analyzed the film production of Moana: The Rising of the Sea, which premiered at the Oceania Film Festival on I 5 April $20{ }_{4} 4$ in Suva, Fiji. According to Hereniko, the film is approximately twelve minutes shorter than the stage production, has additional footage of live climate-change events in the Pacific, and incorporates filmmaking techniques to tighten the drama (pers comm, 23 July 20I4). Further, he explained, "I cut out a whole song at the very end of the film version because it was too hopeful and not quite truthful to lived experience I felt. It took a lot of thinking for me to decide to end it at the scene of disaster but I wanted the viewer to go away realizing the problem is still there and has not been solved or resolved" (Hereniko, pers comm, 23 July 20I4). Though the film is an abbreviated version of the performance and proved challenging in terms of "capturing the strong emotional effect from a stage performance onto film" (Tokalau 20I4), the scenes I analyze appear in both versions. For a review of the stage production premiere, see Miller 2014.

3 Universities and other venues on the tour included the University of California-Los Angeles; the University of California-Riverside; the University of Arizona; Soka University of America; the University of Maryland; New York University; Pennsylvania State University; Wesleyan University; Cornell University; Massachusetts College of Liberal Arts; the Flynn Center for the Performing Arts (Burlington, vT); World Music/CRASHarts (Cambridge, MA); McCallum Theatre (Palm Desert, CA); the Kennedy Center (Washington, DC); and the Museum of Science (Boston, MA).

4 Mitoma had to convince the communities that twelve performers would be sufficient, as Pacific Island communities often favor large groups for performance (Diettrich, Moulin, and Webb 20I I, I6).

5 The European Union is the second largest development donor in the Pacific (Drønen 2013).

6 Though the program notes handed out at each venue were necessarily brief, translations were provided throughout the event, and concertgoers were encouraged to visit the tour's website for more information. The Pennsylvania State University program, for example, explains, "Live performance video projections will provide translation of song texts. For full descriptions and translations, visit www.waterisrising.com" (Pennsylvania State University 20I I).

7 According to Matagi Tokelau, a communally written history of Tokelau, Hemoana is the spirit of Nukunonu. She features in origin stories such as "Hemoana and Fenu," which recounts the creation of Nukunonu's well and the introduction of kie pandanus (Freycinetia sp.) to the atoll (Hooper and Huntsman I99I, I6-I7).

8 In the YouTube post, the title for the song is "The Song of the Frigate Te Itei" (Republic of Kiribati Delegation 2009).

9 Burke explained that the music for ruoia, or Kiribati dances, "may contain passages of harmony in thirds, fourths, or fifths, [though] the singing is usually 
in unison, with men and women an octave apart and simultaneous variants provided by the lead singer" (I998, 76I).

Io In the first delivery of the text, the piece ends on the mediant, while in the second delivery it ends on the tonic.

I I It is important to note that many church leaders at the local level do support climate-change awareness and action and that religious leaders and organizations around the world have taken a strong stance against inaction with regard to climate change. For example, the World Council of Churches and Religions for Peace co-organized an Interfaith Summit on Climate Change, which took place in New York City on 2I-22 September 20I4 (ISCC 20I4), and Vatican Secretary of State Cardinal Pietro Parolin emphasized the Holy See's moral stance on and suggestions for responding to climate change at the United Nations Climate Summit on 23 September 20I4 (Vatican Radio 20I4).

I 2 Kathy Jetnil-Kijiner was selected from over five hundred applicants to represent civil society at the United Nations Climate Summit on 23 September 2014. Her speech, including the poem "Dear Matafele Peinem," addressed to her own infant daughter, received a standing ovation and continues to reverberate around the world. To view the speech, see United Nations 2014.

I 3 This is my interpretation of the scene in the film. At a screening of the film at the Honolulu Museum of Art's Doris Duke Theatre in Honolulu, Hawai'i, on 25 September 20I4, Hereniko explained that in the original script these items, or "seeds," were to be placed in a vault for future generations. While this specific purpose was not clear to me, the intent to carry the items into the future in some way was.

\section{References}

350 Fiji

2013350 Fiji Maroroi Vuravura (Protect the Earth) Pacific Warrior Day of Action. YouTube video. 6 min. Posted by “350 Fiji," 2 March. http://www.youtube.com/watch?v=qiXotk9MPQw [accessed 23 July 2OI3]

350 Pacific

20I3a 350 Pacific: "We Are Not Drowning-We Are Fighting!" YouTube video. 3.5 min. Posted by "350org," 25 July. https://www.youtube .com/watch?v=8xZlswE7IVI [accessed I 3 Aug 20I3]

2013b Pacific Islands: I00\% Possible to Be Heard. 350 Pacific website. https://act.350.org/signup/hundred_percent_possible_pacific _islands [accessed 23 July 2013]

20I3C Warrior Day of Action. 350 Pacific website. http://act.350.org/ signup/warrior_day_of_action/[accessed 23 July 20I3]

2013d We Are Not Drowning. We Are Fighting. 350 Pacific website. http:// 
world.350.org/pacific/we-are-not-drowning-we-are-fighting/ [accessed 23 July 20I3]

20I3e Who We Are. 350 Pacific website. http://world.350.org/pacific/who -we-are/ [accessed 23 July 20I3]

20I4a April I2th, 20I4: Canoe Building Day of Action! 350 Pacific website. http://35opacific.org/our-work/april-I 2th-day-of-action/ [accessed I3 May 20I4]

20I4b 350 Pacific website homepage. http://35opacific.org/ [accessed I 3 May 20I4]

20I4C Pacific Warrior Campaign. 350 Pacific website. http://35opacific.org/ our-work/ [accessed I 3 May 20I4]

Aalbersberg, William, and John Hay

1992 Implications of Climate Change and Sea Level Rise for Tuvalu: Report of a Preparatory Mission. SPREP Reports and Studies Series 54. Apia: South Pacific Regional Environment Programme.

Burke, Mary E Lawson

I998 Kiribati. In Garland Encyclopedia of World Music: Australia and the Pacific Islands, Vol 9, edited by Adrienne L Kaeppler and J W Love, $758-765$. New York: Garland.

Cochran, Patricia, Orville H Huntington, Caleb Pungowiyi, Stanley Tom, F Stuart

Chapin III, Henry P Huntington, Nancy G Maynard, and Sarah F Trainor

2013 Indigenous Frameworks for Observing and Responding to Climate Change in Alaska. Climatic Change I 20 (3): 557-567.

D’Arcy, Paul

2006 The People of the Sea: Environment, Identity, and History in Oceania. Honolulu: University of Hawai'i Press.

Dekker, Rodney, producer

20I I Land: is Life. YouTube video. 2:45 min. Uploaded by "Oxfam Australia,” Io February. http://www.youtube.com/watch?v=6UjxGnZsKVs $\# \mathrm{t}=\mathrm{I} 20$ [accessed 23 Sept 20I4]

Diettrich, Brian, Jane Freeman Moulin, and Michael Webb

20I I Music in Pacific Island Cultures: Experiencing Music, Expressing

Dix, Caitlin V Culture. Global Music Series. New York: Oxford University Press.

20I I Tuvalu: Balancing Climate Change and Development Initiatives in a Small Island Developing State. Master's thesis. Saint Mary's University, Halifax, Nova Scotia.

Drønen, Sverre Ole

2013 Pacific Front Lines of Climate Change. University of Bergen Pacific Studies News, I 8 December. www.uib.no/en/news/5022I/pacificfront-lines-climate-change [accessed 8 July 20I4] 
Dryzek, John S, Richard B Norgaard, and David Schlosberg, editors

20I I The Oxford Handbook of Climate Change and Society. Oxford: Oxford University Press.

Ereth, Adam Christopher

2012 Pacific Atoll Vulnerability to Sea-level Rise, and the Adaptation Strategies to Regional Climate Change. Master's thesis, California State University, Fullerton.

ECOpas, European Consortium for Pacific Studies

20I4 European Consortium for Pacific Studies. Webpage. www.ecopas .info/ [accessed I 5 July 20I4]

ECOPAS and USP, European Consortium for Pacific Studies and the University of the South Pacific

2013a Moana: The Rising of the Sea. Film. 35 min.

2013b Moana: The Rising of the Sea. Program. Available online at http:// www.usp.ac.fj/fileadmin/files/oceania_centre_for_arts_culture_ and_pacific_studies/docs/Programme_Design_email_version.pdf [accessed Io July 20I4]

European Commission

20I4 Anthropology Meets Climate Science in the Pacific. Horizon 2020: The EU Framework Programme for Research and Innovation, I 2 June. http://ec.europa.eu/programmes/horizon2020/en/news/ anthropology-meets-climate-science-pacific [accessed 8 July 20I4]

Farbotko, Carol

2005 Tuvalu and Climate Change: Constructions of Environmental Displacement in the Sydney Morning Herald. Geografiska Annaler: Series B Human Geography 87:279-293.

Fedor, Ilka

2OI2 Cultural and National Identity in the Face of Climate Change: A Case Study of I-Kiribati Migrants in New Zealand. Master's thesis, University of Otago.

Figueroa, Robert Melchoir

20I I Indigenous Peoples and Cultural Losses. In The Oxford Handbook of Climate Change and Society, edited by John S Dryzek, Richard B Norgaard, and David Schlosberg, 232-247. Oxford: Oxford University Press.

Galloway McLean, K, A Ramos-Castillo, T Gross, S Johnston, M Vierros, and R Noa

2010 Report of the Indigenous Peoples' Global Summit on Climate Change: 20-24 April 2009, Anchorage, Alaska. Revised version. Darwin, Australia: United Nations University Institute of Advanced Studies, Traditional Knowledge Initiative. http://www.unutki.org/ 
Garrett, John

downloads/File/Publications/UNU_2009_Climate_Change_Summit _Report_v2.pdf [accessed 27 Jan 20I3]

2000 The Spread of Christian Missions. In The Pacific Islands: An Encyclopedia, edited by Brij V Lal and Kate Fortune, I78. Honolulu: University of Hawai'i Press.

Griggs, Mary Beth

2014 Kiribati's Climate Change Plan B: Buy a New Island Home. Smithsonian.com SmartNews, I 5 July. http:/www.smithsonianmag.com/ smart-news/kiribatis-climate-change-plan-b-buy-new-island-home -I $80952039 /$ [accessed I 5 July 20I4]

Hau'ofa, Epeli

2008 Our Sea of Islands. In We Are the Ocean: Selected Works, 27-40. Honolulu: University of Hawai'i Press.

Hereniko, Vilsoni

2006 Dancing Oceania: The Oceania Dance Theatre in Context. In The $5^{\text {th }}$ Asia-Pacific Triennial of Contemporary Art, edited by Lynne Seear and Suhanya Raffel, 32-42. South Brisbane, QLD: Queensland Art Gallery.

Hooper, Antony, and Judith Huntsman, translators

I99I Matagi Tokelau: History and Traditions of Tokelau. Apia: Office for Tokelau Affairs.

IPCC, Intergovernmental Panel on Climate Change

20I4a Climate Change 20I4: Impacts, Adaptation, and Vulnerability. Part A: Global and Sectoral Aspects. Contribution of Working Group II to the Fifth Assessment Report of the Intergovernmental Panel on Climate Change. Edited by C B Field, V R Barros, D J Dokken, K J Mach, M D Mastrandrea, T E Bilir, M Chatterjee, and others. Cambridge, uk: Cambridge University Press.

20I4b Climate Change 20I4: Impacts, Adaptation, and Vulnerability. Part B: Regional Aspects. Contribution of Working Group II to the Fifth Assessment Report of the Intergovernmental Panel on Climate Change. Edited by V R Barros, C B Field, D J Dokken, M D Mastrandrea, K J Mach, T E Bilir, M Chatterjee, and others. Cambridge, UK: Cambridge University Press.

ISCC, Interfaith Summit on Climate Change

2014 The Statement. New York, 2I September. http://interfaithclimate .org/the-statement [accessed 26 Sept 20I4]

Jetnil-Kijiner, Kathy

20II Tell Them. Iep Jeltok: A Basket of Poetry and Writing from Kathy Jetnil-Kijiner. Blog, I3 April. http://jkijiner.wordpress.com /20I I/O4/I3/tell-them/ [accessed I4 April 20I4] 
2014 Spoken Word Poetry vs Page Poetry. Iep Jeltok: A Basket of Poetry and Writing from Kathy Jetnil-Kijiner. Blog, 25 March. http://jkijiner .wordpress.com/2OI 4/03/25/spoken-word-poetry-vs-page-poetry/ [accessed I 5 July 20I4]

KNTO, Kiribati National Tourism Office

20I3 Kiribati Culture. Kiribati for Travellers website. Updated I3 February. http://www.kiribatitourism.gov.ki/index.php/thingstodo/ culturalexperienceoverview [accessed 23 July 20I3]

Lal, Brij V

2004 Pacific Places, Pacific Histories: Essays in Honor of Robert C. Kiste. Honolulu: University of Hawai'i Press.

Lal, Padma, and Kate Fortune

2000 Climate Change. In The Pacific Islands: An Encyclopedia, edited by Brij V Lal and Kate Fortune, 43-44. Honolulu: University of Hawai'i Press.

Lazrus, Heather

2009 Weathering the Waves: Climate Change, Politics, and Vulnerability in Tuvalu. PhD dissertation, University of Washington.

Lee, Cynthia

20I I Pacific Islanders Reflect "Human Face" of Climate Change. UCLA Today, 5 October.

Lutunatabua, Fenton

20I4 How Pacific Islanders Are Fighting Climate Change with Canoes. GlobalVoices, 20 July. http://globalvoicesonline.org/20I4/07/20/ pacific-islanders-plan-journey-to-australia-canoes-climate-change/ [accessed 20 July 20I4]

Maiava, Mikaele

2013 Short clip warrior dance day of action. YouTube video. I min. Posted by "Mikaele Maiava,” 2 March. http://www.youtube.com/ watch?feature=player_embedded $\& \mathrm{v}=\mathrm{rkGYm_{3 }}$ HEjkY [accessed 6 Aug 20I3]

Majavu, Anna

20I4 Pacific Journalists Challenged to Better Report on Climate Change. Pacific Islands Report, 25 March. http://pidp.eastwestcenter.org/ pireport/20I4/March/03-25-II.htm [accessed I 5 July 20I4]

March, Briar, director 2010 There Once Was an Island: Te Henua e Noho. DVD. 56 min. London: On the Level Productions.

McLean, Roger, and Ana Maria d'Aubert

I993 Implications of Climate Change and Sea Level Rise for Tokelau: Report of a Preparatory Mission. SPReP Reports and Studies Series 6I. Apia: South Pacific Regional Environment Programme. 
Miller, Kara

2014 Review of Moana: The Rising of the Sea. The Contemporary Pacific 26:585-587.

New Zealand Aid Programme

20I 2a Milestone Reached in Tokelau Renewable Energy Project. August. http://www.aid.govt.nz/media-and-publications/development -stories/august-20 I 2/milestone-reached-tokelau-renewable-energy -pr [accessed 27 Jan 2013]

20I2b Tokelau: A Leading Light in Renewable Energy. March. http:// www.aid.govt.nz/media-and-publications/development-stories/ march-20I2/tokelau-leading-light-renewable-energy [accessed 27 Jan 20I3]

Oxfam

2009 The Future Is Here: Climate Change in the Pacific. Oxfam briefing paper. Carlton, vic: Oxfam Australia; Auckland: Oxfam New Zealand.

Pennsylvania State University

20I I Water is Rising: Music and Dance Amid Climate Change, Artists from the Pacific Atolls of Kiribati, Tokelau, and Tuvalu. Performance Program, 8 November. Eisenhower Auditorium.

Peter, Joakim Jojo

2004 Uleletiw: Imaging of My Paradise. In Pacific Places, Pacific Histories: Essays in Honor of Robert C. Kiste, edited by Brij V Lal, 259-274. Honolulu: University of Hawai'i Press.

Republic of Kiribati Delegation, Copenhagen Climate Change Conference

2009 COP I 5 Kiribati side event-Song of the Frigate Te Itei. YouTube video. 6 min. Posted by "Marc Honore," 9 December. http://www .youtube.com/watch?v=G5wEgGZhXrw [accessed 6 Aug 20I3]

Sem, Graham, and Yvonne Underhill

I992 Implications of Climate Change and Sea Level Rise for Cook Islands: Report of a Preparatory Mission. SPREP Reports and Studies Series 57. Apia: South Pacific Regional Environment Programme.

Steiner, Candice Elanna

20I2 Te Kauhiva Tokelau: Composing and Choreographing Cultural Sustainability. Master's thesis. University of Hawai'i, Mānoa.

Sullivan, Marjorie

I99I Environmental Planning, Climate Change and Potential Sea Level Rise: Report on a Mission to Kiribati. Noumea: South Pacific Regional Environment Programme.

Thomas, Allan

I996 New Song and Dance from the Central Pacific: Creating and Per- 
forming the Fātele of Tokelau in the Islands and in New Zealand. Dance and Music Series 9. Stuyvesant, NY: Pendragon Press.

Tokalau, Torika

20I4 Moana: The Rising of the Sea. Fiji Times Online, I7 April. http:// www.fijitimes.com/story.aspx?id=2659I3 [accessed 8 July 20I4]

Tong, Anote

20I4 The Impacts of Climate Change on Kiribati and the Pacific Islands Region: Risk and Resilience. East-West Center, Honolulu, I 3 March. Available online at vimeo.com/890687I4 [accessed Io July 20I4]

UCLA, University of California, Los Angeles

20Ira Science and Art in a Climate of Change: A Dialogue of Nations. YouTube video. I I m min. Posted by "UCtelevision," I 5 December. http://www.youtube.com/watch?v=KwyZrum6QBo [accessed 6 Aug 20I3]

20I Ib Water Is Rising: Music and Dance Amid Climate Change. YouTube video. 89 min. Posted by "UCtelevision," 8 December. http://www .youtube.com/watch?v=8O9IpsfnNMU [accessed 6 Aug 20I3]

\section{United Nations}

20I4 WATCH: Marshallese Poet Kathy Jetnil-Kijiner Speaking at the Climate Summit. 23 September. http://www.un.org/climatechange/ summit/20 I 4/o9/watch-marshallese-poet-kathy-jetnil-kijiner -speaking-climate-summit/ [accessed 26 Sept 20I4]

Urbano, Mia, Nic Maclellan, Tilman Ruff, and Grant Blashki

20I0 Climate Change and Children in the Pacific Islands. Report Submitted to UNICEF Pacific from the Nossal Institute for Global Health, University of Melbourne. April. http://www.sustainable.unimelb.edu .au/files/mssi/UNICEF_report_on_Children_and_Climate_Change _April-20IO.pdf [accessed I Oct 20I4]

Utanga, John, and Taualeo'o Stephen Stehlin, producers

2010 Toku Fenua Ka Galo. Tagata Pasifika: Tuvalu Special King Tides Festival. $30 \mathrm{~min}$. Auckland: Television New Zealand.

Vatican Radio

2014 The Holy See at Climate Summit. 26 September. http://en.radio vaticana.va/news/20I4/o9/26/the_holy_see_at_climate_summit _/I I07373 [accessed 26 Sept 20I4]

Water Is Rising

20I Ia Program Notes. Water Is Rising tour website. http://www.wateris rising.com/content/program-notes-o [accessed 23 July 20I3]

20IIb Water Is Rising tour website. http://www.waterisrising.com [accessed I6 Feb 2012] 


\section{Abstract}

It is estimated that by 2050 as many as 75 million people in the Asia-Pacific region will be forced to migrate from their homelands due to the negative impacts of climate change. While many representations of Pacific Island communities affected by climate change emphasize helplessness, Pacific Islanders have been negotiating identities of empowerment and resilience in both political and cultural arenas. This essay provides an analysis of the messages that Islander performers have chosen to convey through three performance contexts: the 20II Water Is Rising concert tour, which featured groups from Kiribati, Tokelau, and Tuvalu; 350 Pacific's Pacific Warrior Campaign, including both the 2013 Warrior Day of Action and the $20{ }_{4}$ Canoe Building Day of Action; and the multimedia dramatic performance Moana: The Rising of the Sea, written and produced by Vilsoni Hereniko. Through these three campaigns, we can see that Islanders are actively shaping their identity in the face of climate change, choosing to be seen not as victims in a far and rising sea but rather as a sea of warriors with the power to rise up, work together, and make their voices heard in order to save the lands and cultures that they cherish.

KEYWORDS: climate change, performance, identity, Kiribati, Tokelau, Tuvalu, Fiji 